\title{
Rangelia vitalii infection in a dog from São Paulo city, Brazil: case report
}

\section{Infecção por Rangelia vitalli em cão da zona norte de São Paulo/SP: relato de caso}

\author{
Bruna Regina Figura da Silva ${ }^{1,2}$; Marcelo Bahia Labruna ${ }^{3}$; Arlei Marcili ${ }^{1}$; Caio Rodrigues dos Santos ${ }^{4}$; \\ Bárbara Buff Blumer Bastos²; Jessica Tainá Bordin²; Jonas Moraes-Filho ${ }^{1}$ \\ ${ }^{1}$ Universidade Santo Amaro, Curso de Mestrado em Medicina e Bem-Estar Animal, São Paulo - SP, Brazil \\ ${ }^{2}$ Hospital Veterinário São Sebastião, São Paulo - SP, Brazil \\ ${ }^{3}$ Universidade de São Paulo, Faculdade de Medicina Veterinária e Zootecnia, Departamento de Medicina Veterinária Preventiva e Saúde \\ Animal, São Paulo - SP, Brazil \\ ${ }^{4}$ Laboratório Vet-Biotec Biotecnologia e Diagnóstico, Cotia - SP, Brazil
}

\begin{abstract}
Canine rangeliosis is an extravascular hemolytic disease caused by the protozoan Rangelia vitalii, which is transmitted by ticks of the species Amblyomma aureolatum. The most common clinical signs are apathy, hyperthermia and spontaneous bleeding. Anemia and thrombocytopenia are the most common hematological findings. This work reports a clinical case of canine Rangeliosis treated at a private veterinary hospital, in São Paulo city in 2017. A dog was treated at a veterinary hospital in the north of São Paulo, with progressive weight loss, apathy and tail injury. Anemia and thrombocytopenia were observed on the hemogram. Rangelia vitalii DNA was detected in animal blood by real-time PCR (qPCR). In addition to the supportive treatment, doxycycline and subcutaneous imidocarb applications were used. The sample collected after treatment with the antibiotic continued to present protozoal DNA. The disease should be considered as a differential diagnosis and there is a great need for further studies about the therapy used.
\end{abstract}

Keywords: Ticks. Rangeliosis. Bleeding.

\section{RESUMO}

A rangeliose canina é uma doença hemolítica extravascular causada pelo protozoário Rangelia vitalii, o qual é transmitido por carrapatos da espécie Amblyomma aureolatum. Os sinais clínicos mais comuns são apatia, hipertermia e sangramentos espontâneos. Os achados hematológicos mais comuns são anemia e trombocitopenia. Este trabalho teve como objetivo relatar um caso clínico de Rangeliose canina tratada em um hospital veterinário particular, na cidade de São Paulo no ano de 2017. Um cão foi atendido em um hospital veterinário da zona norte de São Paulo, com emagrecimento progressivo, apatia e lesão na cauda. No hemograma foram observadas anemia e trombocitopenia. Através da PCR em tempo real (qPCR) do sangue do animal constatou-se a presença de DNA de Rangelia vitalii. Além do tratamento de suporte, utilizou-se doxiciclina e aplicações subcutâneas de imidocarb. A amostra coletada após o tratamento com o antibiótico continuou apresentando DNA do protozoário. A enfermidade deve ser considerada como diagnóstico diferencial e há uma grande necessidade de maiores estudos acerca da terapia utilizada.

Palavras-chave: Carrapato. Rangeliose. Hemorragia. 
Correspondence to:

Jonas Moraes Filho

Universidade Santo Amaro, Campus I

Rua Professor Enéas de Siqueira Neto, 340, Jardim das Imbuias

CEP: 04829-300, São Paulo - SP, Brazil

e-mail: jmfilho@prof.unisa.br

Received: December 18, 2018

Approved: July 04, 2019

How to cite: Silva BRF, Labruna MB, Marcili A, Santos CR, Bastos BBB, Bordin JT, Moraes-Filho J. Rangelia vitalii infection in a dog from São Paulo city, Brazil: case report. Braz J Vet Res Anim Sci. 2019;56(3):e150791. https://doi. org/10.11606/issn.1678-4456.bjvras.2019.150791

\section{Case Report}

Rangelia vitalii is the etiological agent of canine Rangeliosis, a serious piroplasmosis that affects domestic dogs in Brazil, Uruguay and Argentina (Eiras et al., 2014; Lemos et al., 2012, 2017; Rivero et al., 2017; Soares et al., 2011). It is a protozoan that belongs to the Phylum Apicomplexa, Order Piroplasmorida, which infects dogs, is transmitted by ticks of the species Amblyomma aureolatum, and causes an extravascular hemolytic disorder (Soares et al., 2018).

The existence of wild reservoirs for $R$. vitalii has not yet been confirmed, but it is based on reports of blood smears of piroplasms or molecular detection of $R$. vitalii on canids of the species Lycalopex gymnocercus (Ruas, 2005) and Cerdocyon thous (Paraense \& Vianna, 1948), and on A. aureolatum parasitism in the same wild canid species (Quadros et al., 2015; Soares et al., 2018).

The species A. aureolatum has vectorial competence for $R$. vitalii, since it was able to acquire and transmit the agent among domestic dogs. In contrast, the species A. ovale, A. tigrinum, A. sculptum and Rhipicephalus sanguineus sensu lato were not competent vectors of this protozoan, since they did not acquire the infection after feeding on infected dogs. The same study reports that Amblyomma aureolatum can acquire $R$. vitalii infection by feeding the nymph and adult stages in infected dogs and infection by this agent is maintained in the vector by transovarial transmission and transestadial perpetuation, both from larvae to nymphs and from nymph to adult (Soares et al., 2018).

This protozoan can be seen as free forms in plasma and erythrocytes, monocytes and cytoplasm of endothelial cells, within the cerebral capillaries and in the jugular vein and aorta. It is easier to see the parasite during fever spikes in blood smears (Pestana, 1910; Silva et al., 2011).
Dogs infected with $R$. vitalii are found in marginal rural and urban areas, especially in areas close to the forest, a typical habitat of the A. aureolatum vector (Braga, 1935; Loretti \& Barros, 2005).

The disease can manifest itself in three clinical forms: acute or icteric, subacute or hemorrhagic and chronic forms, the latter being mild or benign (Carini \& Maciel, 1914; Pestana, 1910).

Clinical signs described in dogs with rangeliosis include fever, apathy and prostration (Braga, 1935; Carini \& Maciel, 1914; Fighera et al., 2010; Pocai et al., 1998). Jaundice and anemia are also frequently observed. The spontaneous bleeding is correlated with the intense consumption of platelets, since this protozoan has the capacity to parasite and injure the vascular endothelium, which can occur in the ears and on the skin, which has led to the popular denomination of the disease as "blood plague" or "Nambiuvú", which means "ear that bleeds" in the indigenous Tupi Guarani language. Lesions in the vascular endothelium of vessels that irrigate the digestive system can lead to intestinal changes, as well as the loss of blood into the intestinal lumen, causing a bloody diarrhea that is initially orange, which later becomes dark, often with the presence of blood streaks, making the disease also known as "Nambiuvú of the intestines" (Soares et al., 2018).

Other clinical signs observed are: splenomegaly; generalized enlargement of the lymph nodes; persistent bleeding through the nostrils (epistaxis), oral cavity (including hematemesis), borders and external face of the ears and blood collection sites (venous puncture); petechiae on the visible mucous membranes, and edema of the hind limbs (Carini \& Maciel, 1914; Pestana, 1910).

The most common hematological disorders are anemia, ranging from normocytic to normochromic to macrocytic and hypochromic, and thrombocytopenia (Fighera et al., 2010; Paim et al., 2012). Other abnormalities that have been reported include anisocytosis, polychromasia, Howell-Jolly bodies, and increased reticulocyte counts (Fighera, 2007; Loretti \& Barros, 2004, 2005).

The hematological profile of dogs affected by $R$. vitalii is consistent with an autoimmune extravascular hemolytic anemia (Krauspenhar et al., 2003a, 2003b; Loretti et al., 2003). It has been suggested that this pathogen induces an immune-mediated hemolytic disorder (immune-mediated hemolysis), promoting erythrolysis associated with activation of the complement system and removal of erythrocytes opsonized or antigenically altered by the monocyte-phagocyte system (Krauspenhar et al., 2003a, 2003b; Spagnol et al., 2003). In the leukogram, lymphocytosis (associated with 
antigenic stimulation) and monocytosis are observed. Hemoglobin levels and erythrocyte counts show low values and mean corpuscular volume (MCV) is normal or slightly elevated (Krauspenhar et al., 2003a, 2003b; Loretti et al., 2003; Pestana, 1910; Spagnol et al., 2003). These dogs' plasma is usually jaundiced (Krauspenhar et al., 2003a, 2003b; Loretti et al., 2003). Urine appears cloudy and has a large amount of biliary pigment (marked bilirubinuria secondary to hemolysis), especially in those cases where jaundice is intense (Carini \& Maciel, 1914; Loretti et al., 2003).

The intra-erythrocyte forms of Rangelia vitalii are morphologically very similar to the piroplasm Babesia canis vogeli, which also infects dogs. Therefore, making a morphological diagnosis for species differentiation is not feasible through blood smear examination. The differentiation of these species is made by molecular diagnostics by PCR with specific probes or by sequencing. Recent works have been based on amplification of fragments of the 18S rRNA gene or the heat shock protein 70 (hsp70) (Lemos et al., 2012; Soares et al., 2011, 2018).

The recommended treatment for the disease is doxycycline, imidocarb dipropionate or diminazene aceturate. The same dosage used in the therapy of other protozooses and blood rickets of canines, such as babesiosis and ehrlichiosis, besides the institution of corticotherapy and, when necessary, blood transfusion and fluid therapy have been used (Loretti \& Barros, 2004; Silva et al., 2011). Administration of corticosteroids has been recommended in the treatment of idiopathic or secondary immune-mediated hemolytic anemia (Bücheler \& Cotter, 1995). Regarding the treatment of parasitism by $R$. vitalii with diminazene aceturate, this aromatic diamidine, used in hemoprotozoosis therapy of dogs, is a drug of low therapeutic index and has neurotoxic action in canines (Loretti, 2002; Naudé et al., 1970; Pescador et al., 2003).

This work reports a clinical case of canine Rangeliosis treated at a private veterinary hospital, in the north of São Paulo city in 2017.

On October 26, 2017, a 6-year-old male Rottweiler, resident in a peri-urban area that had access to areas of Atlantic forest fragmentation, had a progressive weight loss history for 1 year was attended at a private veterinary hospital in the north of the city of São Paulo. The animal also had apathy, anorexia and a history of infestations of recurrent ticks, but which were not parasitized at the time of clinical consultation. Physical examination revealed moderate dehydration, hypocorous mucosa, opaque skin and cutaneous lesion in the distal portion of the tail with active mild hemorrhage.
The patient was admitted for venous blood support and blood collection to perform hemoparasite research using molecular techniques and a complete blood count, where thrombocytopenia, macrocytic normochromic anemia and leukocytosis were observed due to neutrophilia and lymphocytosis.

DNA extraction from the blood sample was individually processed using the DNeasy Tissue Kit (Qiagen, Chatsworth, CA, USA), according to the manufacturer's instructions. The DNA extracted from the blood was tested by three realtime PCR protocols, each with an internal probe specific for the following pathogens: Rickettsia spp. (gene gltA), Ehrlichia canis (dsb gene) and Rangelia vitalii (hsp70 gene) (Doyle et al., 2005; Guedes et al., 2005; Labruna et al., 2004; Soares et al., 2018). Only PCR for $R$. vitalii was positive, indicating the presence of this pathogen in the patient's blood.

The period of hospitalization lasted 3 days. The patient received intravenous fluid therapy with Lactate Ringer's solution, complete blood transfusion and imidocarb dipropionate (5 mg/kg, subcutaneously in a single dose), as well as doxycycline ( $5 \mathrm{mg} / \mathrm{kg}$, intravenously every $12 \mathrm{~h}$ ), ranitidine hydrochloride $(2 \mathrm{mg} / \mathrm{kg}$, subcutaneously every $12 \mathrm{~h}$ ) and dipyrone ( $25 \mathrm{mg} / \mathrm{kg}$, subcutaneously every $12 \mathrm{~h}$ ). The use of imidocarb dipropionate and doxycycline was as suggested by Loretti \& Barros (2004) and Silva et al. (2011).

From the second day of hospitalization, the animal presented significant improvement, illustrated by the most stained mucosa, normorexia, normodipsia, normouria and normoquesia. The tail lesion received bandages every $12 \mathrm{~h}$ with compressive bandage, and the hemorrhage ceased within a short time after the admission of the patient to the hospital.

At the end of the third day, the patient was discharged with a prescription of $5 \mathrm{mg} / \mathrm{kg}$ doxycycline orally every $12 \mathrm{~h}$ for 28 days and ranitidine hydrochloride $2 \mathrm{mg} / \mathrm{kg}$ orally every $12 \mathrm{~h}$ for 28 days. The return for reassessment occurred after 2 days of discharge when a new sample was collected for hemogram, evidencing a large increase in total platelet count and slight improvement in hematocrit, but still with leukocytosis due to neutrophilia and lymphocytosis, in addition to normochromic anemia.

The guardian did not return on the day scheduled for the application of the second dose of imidocarb dipropionate. Then, after 2 months of the first dose, the patient was again taken to the veterinary hospital presenting apathy, hyporexia, abdominal distension and skin lesion with myiasis in portion distal region of the left pelvic limb, in addition to the presence of ticks identified as A. aureolatum. 
Abdominal ultrasound revealed splenomegaly. A new blood sample was collected for hemogram and molecular analysis.

The DNA extracted from the second sample also presented a positive result for $R$. vitalii and the hemogram found thrombocytopenia and normochromic normocytic anemia, but with hematocrit increase in relation to the last sample.

The patient remained hospitalized for $24 \mathrm{~h}$ receiving supportive care, dressings and a second dose of imidocarb dipropionate ( $5 \mathrm{mg} / \mathrm{kg}$, subcutaneously). It was discharged with good clinical improvement and indication of tick control and dressing on the skin lesion.

The clinical manifestations presented by the patient, such as anorexia, hemorrhage, apathy, weight loss and dehydration, are in agreement with what is described in the literature as the classic form of canine rangeliosis (Carini \& Maciel, 1914; Fighera et al., 2010; Moreira, 1939; Pestana, 1910).

Although not a pathognomonic clinical sign of $R$. vitalii infection, ear-tip bleeding has been described due to the intense consumption of platelets and the endothelial lesion caused by the parasite, experimentally related to insect bites or local lesions (Andrade, 2007). Case reported was observed during the first physical examination bleeding at the body end (distal portion of the tail).

Decreases in the total number of red blood cells, hemoglobin concentration and hematocrit were found in the three hemograms performed, in addition to thrombocytopenia in the first and last exam. These are changes similar to those caused by babesiosis (Paim et al., 2012).

The anemic picture presented by the animal ranged from normocytic anemia to normochromic macrocyticum, data consistent with the literature, which cites autoimmune regenerative anemias as the most found in patients affected by rangeliosis (Fighera et al., 2010; Paim et al., 2012).

Lymphocytosis developed by the patient may be associated with the antigenic stimulation described by Loretti \& Barros (2004). In addition, the possible immunomediated character of hemolytic anemia caused by R. vitalii (Fighera et al., 2010; Krauspenhar et al., 2003a; Loretti \& Barros, 2005), may be the cause of leukocytosis due to neutrophilia seen in the patient in question.

\section{References}

Andrade ES. Infecções causadas por hematozoários de cães e gatos de ocorrência no Brasil: semelhanças e particularidades
Supporting treatment, such as fluid therapy and blood transfusion, was performed in the patient of the present report. The treatment of doxycycline suggested by Moreira (1939) and Loretti \& Barros (2004) did not prove effective in the described case, in which, after the administration of this antibiotic, the patient still had clinical alterations associated with the presence of hemoparasite DNA in the blood sample collected. The efficacy of imidocarb dipropionate could not be proven due to the lack of return of the tutor with the dog to collect a third sample of blood for PCR, probably due to clinical improvement of the animal, but the patient had the best values in the parameters of blood count after application of a second dose of the drug and clinical worsening was observed even after the first administration of the drug, differently than reported by Silva et al. (2011), in which authors describe the efficiency in the treatment of canine Rangeliose with a single dose of imidocarb dipropionate.

Canine rangeliosis is a poorly diagnosed disease that can cause serious complications for affected animals. It is extremely important that it is considered a differential diagnosis when clinical manifestations and laboratory findings such as hemorrhage, weight loss, anemia, thrombocytopenia and splenomegaly are observed. In the case reported, treatment with doxycycline was not effective, contrary to previously unpublished data in the scientific literature, and additional studies are necessary in relation to the treatment of the disease.

\section{Conflict of Interest}

The authors state that they have no conflicts of interest to declare.

\section{Ethics Statement}

This study was evaluated by the Animal Research Ethics Committee of the Santo Amaro Univeristy and was approved under Protocol no 44.1/2017.

\section{Acknowledgements}

Thanks to the Foundation for Research Support São Paulo (FAPESP) for all the financial support (process number 2016/00167-0).

[monografia]. Porto Alegre: Universidade Federal do Rio Grande do Sul; 2007. 
Braga A. Contribuição ao estudo experimental das piroplasmoses dos cães. Bol Veter Exército. 1935;3:1-16.

Bücheler J, Cotter SM. Canine immune-mediated hemolytic anemia. In: Bonagura JD, Kirk RW, editors. Kirk's current veterinary therapy XII: small animal practice. Philadelphia: WB Saunders; 1995. p. 152-7.

Carini A, Maciel J. Sobre a moléstia dos cães, chamada nambi-uvú, e o seu parasita (Rangellia vitalli). An Paul Med Cir. 1914;3(2):65-71.

Doyle CK, Labruna MB, Breitschwerdt EB, Tang YW, Corstvet RE, Hegarty BC, Bloch KC, Li P, Walker DH, Mcbride JW. Detection of medically important Ehrlichia by quantitative multicolor TaqMan real-time polymerase chain reaction of the dsb gene. J Mol Diagn. 2005;7(4):504-10. http://dx.doi. org/10.1016/S1525-1578(10)60581-8. PMid:16237220.

Eiras DF, Craviotto MB, Baneth G, Moré G. First report of Rangelia vitalii infection (canine rangeliosis) in Argentina. Parasitol Int. 2014;63(5):729-34. http://dx.doi.org/10.1016/j. parint.2014.06.003. PMid:24970768.

Fighera RA. Rangeliose. Acta Sci Vet. 2007;35(2):261-3.

Fighera RA, Souza TM, Kommers GG, Irigoyen LF, Barros CSL. Patogênese e achados clínicos, hematológicos e anatomopatológicos da infecção por Rangelia vitalii em 35 cães (1985-2009). Pesq Vet Bras. 2010;30(11):974-87. http://dx.doi.org/10.1590/S0100-736X2010001100012.

Guedes E, Leite RC, Prata MCA, Pacheco RC, Walker $\mathrm{DH}$, Labruna MB. Detection of Rickettsia rickettsii in the tick Amblyomma cajennense in a new Brazilian spotted fever-endemic area in the state of Minas Gerais. Mem Inst Oswaldo Cruz. 2005;100(8):841-5. http://dx.doi.org/10.1590/ S0074-02762005000800004. PMid:16444414.

Krauspenhar C, Fighera RA, Barros CSL, Graça DL. Protozoa-related imune mediated hemolytic anemia: case report. In: Proceedings of the Seventh Biennal Conference of the Society for Tropical Veterinary Medicine; 2003 June 22-26; Foz do Iguaçu. Foz do Iguaçu: Mabu Thermas \& Resort Iguaçu Falls; 2003a.

Krauspenhar C, Fighera RA, Graça DL. Anemia hemolítica em cães associada a protozoários. Rev Cientif Med Vet Pequenos Anim Estim. 2003b;1(4):273-81.

Labruna MB, Whitworth T, Horta MC, Bouyer DH, Mcbride JW, Pinter A, Popov V, Gennari SM, Walker DH. Rickettsia species infecting Amblyomma cooperi ticks from an area in the state of São Paulo, Brazil, where Brazilian spotted fever is endemic. J Clin Microbiol. 2004;42(1):90-8. http:// dx.doi.org/10.1128/JCM.42.1.90-98.2004. PMid:14715737.

Lemos TD, Cerqueira AM, Toma HK, Silva AV, Corrêa RG, Paludo GR, Massard CL, Almosny NR. Detection and molecular characterization of piroplasms species from naturally infected dogs in southeast Brazil. Rev Bras Parasitol Vet. 2012;21(2):137-42. http://dx.doi.org/10.1590/ S1984-29612012000200012. PMid:22832754.

Lemos TD, Toma HK, Assad RQ, Silva AVD, Corrêa RGB, Almosny NRP. Clinical and hematological evaluation of Rangelia vitalii-naturally infected dogs in southeastern Brazil. Rev Bras Parasitol Vet. 2017;26(3):307-13. http:// dx.doi.org/10.1590/s1984-29612017040. PMid:28902259.

Loretti AP. Focal symmetrical hemorrhagic encephalomalacia associated with diminazene aceturate therapy in a dog. In: Anales de la IIIa Reunión Argentina de Patología Veterinaria (RAPAVE); 2002 Nov 27-29; Rosario, Santa Fe. Santa Fe: Facultad de Ciencias Veterinarias, Universidad Nacional de Rosario; 2002. p. 54.

Loretti AP, Barros SS. Parasitismo por Rangelia vitalii em cães ("nambiuvú", "peste de sangue"): uma revisão crítica sobre o assunto. Arq Inst Biol. 2004;71(1):101-31.

Loretti AP, Barros SS. Hemorrhagic disease in dogs infected with an unclassified intraendothelial piroplasm in southern Brazil. Vet Parasitol. 2005;134(3-4):193-213. http://dx.doi. org/10.1016/j.vetpar.2005.07.011. PMid:16153781.

Loretti AP, Barros SS, Corrêa AM, Breitsameter I, Oliveira LO, Pescador CA, Silva NN, Rozza DB, Driemer D, Araujo ACP, Meireles LR. Parasitism of dogs by Rangelia vitalli in Southern Brazil: clinical, pathological and ultrastructural study. In: Anais do XI Encontro Nacional de Patologia Veterinária (ENAPAVE); 2003; Botucatu. Jaboticabal: FUNEP; 2003. p. 178.

Moreira J. O nambiuvú. Biologico. 1939;6:113-6.

Naudé TW, Basson PA, Pienaar JG. Experimental diamidine poisoning due to commonly used babecides. Onderstepoort J Vet Res. 1970;37(3):173-84. PMid:5526279.

Paim CB, Paim FC, Silva AS, França RT, Costa MM, Leal CA, Soares JF, Labruna MB, Schetinger MR, Mazzanti A, Mazzanti CM, Monteiro SG, Lopes ST. Thrombocytopenia and platelet activity in dogs experimentally infected with 
Rangelia vitalii. Vet Parasitol. 2012;185(2-4):131-7. http:// dx.doi.org/10.1016/j.vetpar.2011.09.039. PMid:22019200.

Paraense WL, Vianna YL. Algumas observações sobre a babesiose dos cães no Rio de Janeiro. Mem Inst Oswaldo Cruz. 1948;46(3):595-603. http://dx.doi.org/10.1590/S007402761948000300005.

Pescador CA, Loretti AP, Both AC. Intoxicação por aceturato de diminazeno em um canino: relato de caso. In: Anais do XI Encontro Nacional de Patologia Veterinária (XI ENAPAVE); 2003 Jul 21-25; Botucatu. Jaboticabal: FUNEP; 2003. p. 62.

Pestana BR. O nambiuvú. Rev Med. 1910;22:423-6.

Pocai EA, Frozza L, Headley SA, Graça DL. Leishmaniose visceral (calazar): cinco casos em cães de Santa Maria, Rio Grande do Sul, Brasil. Cienc Rural. 1998;28(3):501-15. http://dx.doi.org/10.1590/S0103-84781998000300025.

Quadros RM, Soares JF, Xavier JS, Pilati C, Costa JL, Miotto BA, Miletti LC, Labruna MB. Natural Infection of the Wild Canid Lycalopex gymnocercus by the Protozoan Rangelia vitalii, the Agent of Canine Rangeliosis. J Wildl Dis. 2015;51(3):787-9. http://dx.doi.org/10.7589/2014-08194. PMid:25932667.

Rivero R, Minoli P, Parodi P, Matto C, Armúa-Fernández MT, Gianneechini E, Carvalho L, Venzal JM. Descripción de un foco de rangeliosis canina en el litoral noroeste del Uruguay. Veterinaria. 2017;54(208):15-22. http://dx.doi. org/10.29155/VET.23.208.1.

Ruas JL. Caracterização da fauna parasitária do Pseudalopex gymnocercus (graxaim do campo) e do Cerdocyon thous (graxaim do mato) na região sul do Rio Grande do Sul [tese]. Porto Alegre: Universidade Federal do Rio Grande do Sul; 2005.
Silva AS, França RT, Costa MM, Paim CB, Paim FC, Dornelles GL, Soares JF, Labruna MB, Mazzanti CM, Monteiro SG, Lopes STA. Experimental infection with Rangelia vitalii in dogs: acute phase, parasitemia, biological cycle, clinical-pathological aspects and treatment. Exp Parasitol. 2011;128(4):347-52. http://dx.doi.org/10.1016/j. exppara.2011.04.010. PMid:21570966.

Soares JF, Costa FB, Girotto-Soares A, Da Silva AS, França RT, Taniwaki SA, Dall'Agnol B, Reck J, Hagiwara MK, Labruna MB. Evaluation of the vector competence of six ixodid tick species for Rangelia vitalii (Apicomplexa, Piroplasmorida), the agent of canine rangeliosis. Ticks Tick Borne Dis. 2018;9(5):1221-34. http://dx.doi.org/10.1016/j. ttbdis.2018.05.004. PMid:29752143.

Soares JF, Girotto A, Brandão PE, Silva AS, França RT, Lopes STA, Labruna MB. Detection and molecular characterization of a canine piroplasm from Brazil. Vet Parasitol. 2011;180(34):153-67. http://dx.doi.org/10.1016/j.vetpar.2011.03.024. PMid:21489694.

Spagnol C, Loretti A, Correa A, Pescador C, Rozza D, Conceição E, Colodel EM, Oliveira RT, Breitsameter I, Barros SS, Oliveira LC. Parasitismo de cães por Rangelia vitalli no Estado do Rio Grande do Sul. In: Resumos do XV Salão de Iniciação Científica; XII Feira de Iniciação Científica; 2003; Porto Alegre. Porto Alegre: PROPESQ; 2003.p. 232-3.

Financial Support: Foundation for Research Support São Paulo (FAPESP) - process number 2016/00167-0.

Authors Contributions: Bruna Regina Figura da Silva, Marcelo Bahia Labruna, Arlei Marcili, Caio Rodrigues dos Santos, Bárbara Buff Blumer Bastos, Jessica Tainá Bordin and Jonas Moraes Filho participated in clinical, laboratory activities and also in writing the article considering the reading and review stages. 